\title{
ANALISIS STRATEGI FUNDRAISING ZAKAT DALAM MENINGKATKAN JUMLAH MUZAKKI Studi pada LAZ BaitulMaalKu Kabupaten Karawang
}

\author{
Arief Teguh Nugroho', Ali Nur Ahmad ${ }^{2}$, Wirjo Wijoyo ${ }^{3}$ \\ 1 Universitas Pelita Bangsa, ariefteguhnugroho@gmail.com \\ 2 Universitas Pelita Bangsa, ali.ahmad@pelitabangsa.ac.id \\ 3 Universitas Pelita Bangsa,wirjowijoyo17@gmail.com
}

\section{A R T I C L E I N F O}

Article history:

Received : 28/03/2021

Revised : 29/03/2021

Accepted: 05/04/2021

Key words:

Strategy; zakat fundraising; LAZ

BaitulMaalKu Karawang Regency.

DOI:

Doi.org/10.37366/jespb.v6i01.179

\section{A B S T R A C T}

The zakat fundraising strategy is an effort to collect zakat from individuals or business entities to achieve zakat goals. The main source of zakat fundraising is muzakki. So considering that the zakat fundraising process is fundamental to zakat management efforts, parties who have been given the authority to manage zakat must be able to convince the Muslim community about the importance of zakat. The fundraising strategy that has been implemented has not been able to achieve zakat potential and zakat fundraising targets in Karawang Regency. And the offline fundraising strategy has not been optimal in increasing the amount of funds and the number of muzakki in Karawang Regency. And this research is how the constraints in the fundraising strategy at LAZ BaitulMaalKu, Karawang Regency.

This research uses qualitative methods, data collection with 3 methods, namely: observation, interviews, and documentation. After the data is collected, the next step, with the analysis stages, namely, data reduction, data presentation and drawing conclusions. The results of the research carried out are zakat fundraising strategies in increasing the number of muzakki at LAZ BaitulMaalKu, namely using 2 (two) strategies, the first is Direct Strategy (Offline) such as fundraising campaign, zakat pick-up services, and fundraising retail, namely the socialization and education of zakat to majelis taklim and companies. company. Second, the strategy is indirect (online) or indirectly, including through good friends channels, social media, through zakat accounts, and payroll or partnerships with corporations in Karawang. The strategy that is considered the most effective is the indirect strategy (online), namely payroll through the transfer of a partnership cooperation account with a corporation in Karawang.

For factors driving the zakat fundraising strategy in increasing the number of muzakki at LAZ BaitulMaalKu, namely Institutional Legality, Monthly Compensation for the Elderly, Mustahiq empowerment programs, scholarships for dhuafa/outstanding students, and other programs that can make muzakki interested fulfill it in BaitulMaalku. While the inhibiting factor for the zakat fundraising strategy at LAZ BaitulMaalKu, namely knowledge about zakat in some communities is still lacking, some people believe more in religious figures and there are also people who channel directly, the Amil Zakat Institution is flourishing in the midst of society despite the legality of the institution. No, and the Islamic philanthropic institute LAZNAS is conducting fundraising in Karawang Regency.

\section{A B S T R A K}

Strategi fundraising zakat merupakan upaya mengumpulkan zakat dari perorangan atau badan usaha untuk mencapai tujuan zakat. Sumber utama fundraising zakat adalah muzakki. Maka mengingat proses fundraising zakat merupakan hal yang mendasar bagi upaya pengelolaan zakat, pihak-pihak yang telah diberi wewenang untuk mengelola zakat harus mampu meyakinkan masyarakat muslim mengenai pentingnya zakat. Strategi fundraising yang 
diterapkan belum mampu mencapai potensi zakat dan target fundraising zakat yang ada di Kabupaten Karawang. Dan belum optimalnya strategi fundraising langsung (offline) dalam meningkatkan jumlah dana dan jumlah muzakki di Kabupaten Karawang. Dan penelitian ini adalah bagaimana kendala-kendala dalam strategi fundraising di LAZ BaitulMaalKu Kabupaten Karawang.

Penelitian ini menggunakan metode kualitatif, pengambilan data dengan 3 metode yaitu: observasi, wawancara, dan dokumentasi. Setelah data terkumpul, langkah selanjutnya, dengan tahapan analisis yaitu, reduksi data, penyajian data dan penarikan kesimpulan. Hasil dari penelitian yang dilakukan adalah strategi fundraising zakat dalam meningkatkan jumlah muzakki di LAZ BaitulMaalKu, yaitu menggunakan 2 (dua) strategi, yang pertama Strategi Langsung (Offline), seperti Kampanye fundraising pelayanan jemput zakat, dan ritel fundraising yaitu sosialisasi dan edukasi zakat ke majelis taklim dan perusahaan-perusahaan. Kedua, Strategi tidak langsung (online), diantaranya melalui kanal sahabat kebaikan, media-media sosial, melalui rekening zakat, dan payroll atau kerjasama kemitraan dengan korporasi yang ada di Karawang. Strategi yang dinilai paling efektif adalah strategi tidak langsung (online), yaitu payroll melalui transfer rekening kerjasama kemitraan dengan korporasi yang ada di Karawang.

Untuk faktor-faktor pendorong strategi fundraising zakat dalam meningkatkan jumlah muzakki di LAZ BaitulMaalKu, diantaranya, Legalitas Lembaga, program-program Santunan Jompo setiap bulan, program pemberdayaan mustahik, Beasiswa dhuafa/siswa-siswi berprestasi, Dan program-program lainnya yang bisa membuat muzakki tertarik menunaikannya di BaitulMaalKu. Sedangkan faktor penghambat strategi fundraising zakat di LAZ BaitulMaalKu, yaitu, Pengetahuan tentang zakat sebagian masyarakat masih kurang, sebagian masyarakat lebih percaya kepada tokoh-tokoh agama dan ada juga masyarakat yang menyalurkan secara langsung, Lembaga Amil Zakat berjamuran di tengah-tengah masyarakat walaupun legalitas lembaga tersebut tidak ada, dan Lembaga filantropi Islam LAZNAS melakukan fundraising di Karawang.

\section{PENDAHULUAN}

Strategi fundraising merupakan peranan penting bagi Lembaga Amil Zakat (LAZ) dalam menjalankan aktivitasnya. Strategi fundraising dapat mendorong pengelolaan dana ZIS (Zakat, Infak, Sedekah) dalam meningkatakan jumlah dana yang diperoleh sangat menentukan berjalannya berbagai program dan kegiatan pemberdayaan mustahik, seperti ekonomi, pendidikan, kesehatan, sosial kemanusiaan dan dakwah, serta dalam pengelolaan operasional lembaga non-profit. Pada umumnya, strategi fundraising bisa dilakukan dengan beberapa cara, dengan secara langsung (direct fundraising), seperti jemput zakat, pemasangan spanduk (Banner), menyebarkan kotak zakat, infaq, sedekah (kencleng), memberikan pengajian-pengajian rutin di majelis taklim, dan kemitraan. Strategi tersebut dimilki di berbagai LAZ untuk menarik donatur atau muzakki.

Dengan berkembangnya dinamika kehidupan, strategi fundraising bergeser kearah digital yang lebih praktis dan efisien dengan strategi fundraising tidak langsung (indirect fundraising) atau daring (online), seperti website, direct email, sosial media, media campaign, rekening bank, yang mampu menjangkau jaringan yang lebih luas dalam menggalang dana perorangan, perusahaan dan pemerintah. Penghimpunan (fundraising) dana zakat boleh dikatakan selalu menjadi tema menarik dalam Forum Zakat (FOZ). Sebenarnya pengaturan fundraising zakat begitu sederhana namun memerlukan pengetahuan khusus. Pelaksanaan 
pemungutan zakat semestinya, mampu secara ekonomi dapat menghapus tingkat perbedaan kekayaan yang mencolok, serta sebaliknya dapat menciptakan redistribusi yang merata. (Mannan, 1997; 248).

Proses fundraising zakat dalam konteks masa kini, lebih banyak megikuti konsep fundraising, yaitu hal yang sangat mendasar bagi upaya pengelolaan zakat, pihak-pihak yang telah diberi wewenang untuk mengelola zakat harus mampu meyakinkan masyarakat muslim mengenai pentingnya zakat. Oleh sebab itu, para pengurus LAZ sebaiknya memiliki kapasitas untuk melakukan hal-hal seperti, mempengaruhi, memberitahukan, mengingatkan, membujuk, merayu dan mendorong, agar tercipta kesadaran, motivasi, dan kepedulian terhadap penunaian zakatnya melalui LAZ. (Direktorat Pemberdayaan Zakat, 2013: 48-49). Persoalan utama yang menyebabkan rendahnya realisasi fundraising zakat yaitu akibat keterbatasan pemahaman umat Islam tentang arti dan esensi zakat. Padahal, kesadaran dan pemahaman mengenai zakat pada masyarakat ini sangat penting untuk dapat mengoptimalkan dana zakat dari umat Islam. (Sudjatmiko, 2018).

Selain itu, prinsip penunaian zakat dengan cara tradisional yang lebih memilih menyalurkan zakat di lingkungan terdekatnya, langsung kepada para mustahik. Cara pengumpulan zakat semacam ini cenderung tidak terkondisikan dengan baik sehingga tidak menutup kemungkinan adanya penerima manfaat ganda dan motivasi para mustahik untuk tumbuh dan berkembang relatife lebih kecil dibandingkan dengan program pemberdayaan yang terorganisasi dengan baik oleh LAZ (Ghofur, 2018: 8). Salah satu daerah yang juga memiliki potensi zakat yang cukup besar adalah Kabupaten Karawang, yang merupakan daerah industri. Sampai saat ini tercatat 19.000 Hektare lahan yang dialokasikan untuk sektor industri, dengan jumlah sebanyak 8.900 perusahaan membuat Karawang sebagai kota industri terbesar di Indonesia. Karawang juga memiliki tingkat UMR (Upah Minimum Region) terbesar di Indonesia, yakni mencapai 4,2 juta perbulan tahun 2019. Berdasarkan hal tersebut dapat dipastikan bahwa masyarakat
Karawang akan jauh lebih sejahtera jika dibandingkan dengan masyarakat Kabupaten yag lain. (Burhani, 2013).

Jumlah upah minimum di Kabupaten Karawang tiap tahunnya terus mengalami peningkatan, hal ini tentunya dapat berpengaruh terhadap jumlah pendapatan masyarakat Kabupaten Karawang yang juga mengalami kenaikan. Menurut Kurnia adam selaku ketua BAZNAS Kabupaten Karawang, potensi zakat di Kabupaten Karawang sebesar Rp.667 miliyar, namun dana zakat di Kabupaten Karawang hanya dapat terkumpul kurang lebih sebesar 0,6 persen dari potensi zakat, atau sekitar Rp 4 Miliyar. (Burhani, 2013). Dari sekian banyaknya LAZ di Tanah Air, peneliti tertarik dengan LAZ BaitulMaalKu Kabupaten Karawang, yang berdiri di tahun 2017. LAZ BaitulMaalKu Kabupaten Karawang merupakan lembaga zakat tingkat Kabupaten/Kota yang amanah dan akuntabel dalam pemberdayaan umat yang sesuai dengan kebutuhan asasi manusia melalui pendayagunaan secara produktif dana zakat, infaq, sedekah dan wakaf. LAZ BaitulMaalKu Kabupaten Karawang merupakan LAZ berskala Kabupaten pertama di Karawang, denga SK Kemenag No. 1676 Tahun 2019 tanggal 19 Desember 2019. SK Baznas No. 674/ANG/HVR/SDP/BAZNAS/XI/2019.

LAZ BaitulMaalKu mempunyai sasaran strategi fundraising zakat yang secara langsung kepada pengusaha, karyawan, petani dan perusahaanperusahaan yang ada di wilayah Karawang dan Purwakarta. Kinerja fundraiser (Pelaku fundraising) untuk strategi ini belum optimal, namun dengan waktu singkat, mampu meraih penghimpunan dana ZIS yang cukup tinggi untuk memenuhi syarat memperoleh legalitas sebagai LAZ tingkat Kabupaten/kota di tahun 2019 dengan strategi fundraising Kemitraan Korporasi. Sebagaimana dimaksudkan dalam Pasal 56 Peraturan Pemerintah Republik Indonesia Nomor 14 Tahun 2014 Tentang Pelaksanaan Undang-Undang Nomor 23 Tahun 2011 Tentang Pengelolaan Zakat, serta memenuhi syarat fundraising minimal yang ditetapkan dalam KMA Nomor 333 Tahun 2015 sebesar 3 Miliyar 
fundraising dana ZIS untuk tingkat Kabupaten/Kota.

LAZ BaitulMaalKu mampu memperoleh dana zakat mencapai Rp.2.133.415.000 di tahun 2019, lebih dari 1000 muzakki. Pada tahun sebelumnya, di tahun 2018 dengan hanya memperoleh penerimaan dana zakat sebesar Rp.22.500.000 dengan jumlah Muzakki sebanyak 171. Namun jumlah tersebut belum mampu mencapai target jumlah penerimaan dana zakat yang ditetapkan BaitulMaalKu Lebih dari Rp.2,2 M untuk potensi Kabupaten Karawang dilihat dari kemampuan LAZ BaitulMaalKu sebagai LAZ yang terbilang baru. Dibalik hasil pencapaian yang bagus di tahun 2019, dari total penerimaan dana zakat Rp.2.133.415.000, terjadi penurunan dalam strategi fundraising yang secara langsung (offline) atau diluar dari penerimaan dana zakat kemitraan korporasi, hanya mampu memperoleh dana sebesar Rp.2.167.500 dalam 1 tahun.

LAZ BaitulMaalKu Kabupaten Karawang, merupakan LAZ dengan manajemen modern yang diharapkan dapat menghantarkan zakat menjadi bagian dari penyelesaian masalah (problem solver) atas kondisi kemasyarakatan yang terus berkembang, namun dengan strategi fundraising yang sudah ada masih belum maksimal dalam meningkatkan jumlah muzakki dan jumlah penerimaan dana, berdasarkan target tahunan yang di tetapkan LAZ itu sendiri, dan berdasarkan potensi besar yang ada di Kabupaten Karawang. Fokus penelitian ini adalah untuk menjelaskan bagaimana strategi fundraising LAZ BaitulMaalKu Kabupaten Karawang dalam mendapatkan dan meningkatkan jumlah muzakki di Kabupaten Karawang. Selain itu, apa saja faktor pendukung dan penghambat LAZ BatulMaalKu Kabupaten Karawang dalam meningkatkan jumlah muzakki.

\section{Rumusan Masalah}

Berdasarkan uraian pada latar belakang yang telah dijabarkan di atas, maka penulis merumuskan masalah sebagai berikut:

1) Bagaimana analisis strategi fundraising zakat dalam meningkatkan jumlah muzakki di LAZ BatulMaalKu Kabupaten Karawang?
2) Apa faktor pendukung dan penghambat strategi fundraising zakat dalam meningkatkan jumlah muzakki di LAZ BaitulMaalKu Kabupaten Karawang?

\section{Tujuan Penelitian}

Berdasarkan rumusan masalah di atas, maka penelitian ini bertujuan sebagai berikut:

1) Menganalisis strategi fundraising zakat dalam meningkatkan jumlah muzakki di LAZ BaitulMaalKu Kabupaten Karawang.

2) Mengamati faktor pendukung dan penghambat strategi fundraising zakat dalam meningkatkan jumlah muzakki di LAZ BaitulMaalKu Kabupaten Karawang.

\section{TINJAUAN TEOIRITIS}

\section{Strategi}

WF Glueck dan LR Jauch dalam buku "Manajemen strategis dan kebijakan perusahaan". mendefinisikan strategi sebagai rencana yang disatukan, luas dan berintegrasi yang menghubungkan keunggulan strategis perusahaan dengan tantangan lingkungan, yang dirancang untuk memastikan bahwa tujuan utama dari perusahaan dapat dicapai melalui pelaksanaan yang tepat oleh organisasi. Perusahaan disini bisa diidentikan dengan lembaga amil zakat. (Chaniago, 2014:89).

\section{Fundraising}

Andreasen dan Kotler (2008) mendefinisikan sebagai aktivitas fundraising mengidentifikasi sumber utama dana dan mengumpulkan sumber daya keuangan lembaga. Mereka menjelaskan lebih lanjut bahwa fundraising saat ini telah mencapai titik orientasi pemasaran dalam perkembangannya, di mana ia tidak hanya sekedar membuat permintaan pendanaan moneter pada nama penerima manfaat, melainkan beroperasi melalui pertukaran nilai juga memenuhi kebutuhan donor. Dengan demikian, kegiatan fundraising dapat mencakup pengumpulan dan kegiatan pemasaran. 


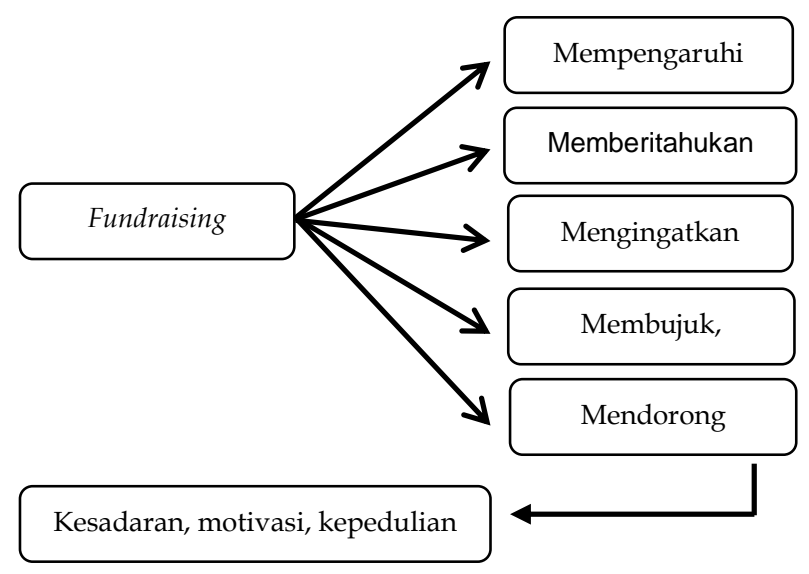

Gambar 1. Skema Fundraising

\section{Urgensi Fundrising Bagi Lembaga Zakat}

Kenapa Fundraising, alasan pertama adalah untuk survive. Dana yang diperoleh organisasi akan digunakan untuk keberlangsungan dari organisasi itu sendiri. Seperti untuk biaya operasional, program, gaji karyawan maupun Amil, dan lain sebagainya. Kedua, dengan penggalangan dana, Organisasi dapat mengurangi ketergantungannya kepada pihak tertentu. Banyak organisasi pelayanan kemanusiaan yang bergantung pada satu atau dua donatur saja. Hal ini menjadikan lembaga tersebut bergantung pada donatur tersebut. Dapat dibayangkan kalau donatur tersebut bangkrut atau tak mau lagi membantu organisasi? Oleh karena itu upaya fundraising diperlukan untuk membuka jaringan donatur seluas-luasnya. Ketiga adalah untuk Perluasan dan Pengembangan Organisasi. Tentunya untuk menghadapi masa depan yang lebih cerah organisasi harus berkembang dan memperluas kegiatan pelayanan, dan untuk melakukan ini, Organisasi membutuhkan bantuan dari banyak donatur. Keempat, dengan fundraising, organisasi dapat mengembangkan constituency. Jadi, organisasi tidak hanya mendapatkan bantuan dana, tapi juga dukungan secara moral legal dan lain-lain. Yang tentunya ini akan berimbas pada eksistensi relawan pada organisasi tersebut. Kelima, dengan fundraising, organisasi menciptakan sustainibility. penggalangan dana bukan saja ditujukan untuk hari esok, atau setahun ke depan. tapi dengan sistem yang baik dan perencanaan yang tepat, organisasi dapat melangsungkan keberlangsungan hidupnya sampai masa depan. (Abidah, 2016: 176).

\section{Muzakki}

Muzakki adalah orang yang wajib mengeluarkan zakat telah di sepakati oleh ulama bahwa zakat hanya diwajibkan kepada seorang muslim, merdeka, dewasa yang berakal, yang memiliki kekayaan dalam jumlah tertentu dengan syarat tertentu (Qardhawi, 1999: 95).

\section{Kerangka Pikir}

Untuk menggambarkan penjabaran dari latar belakang penelitian ini dapat dituangkan dalam kerangka pemikiran sebagai berikut:

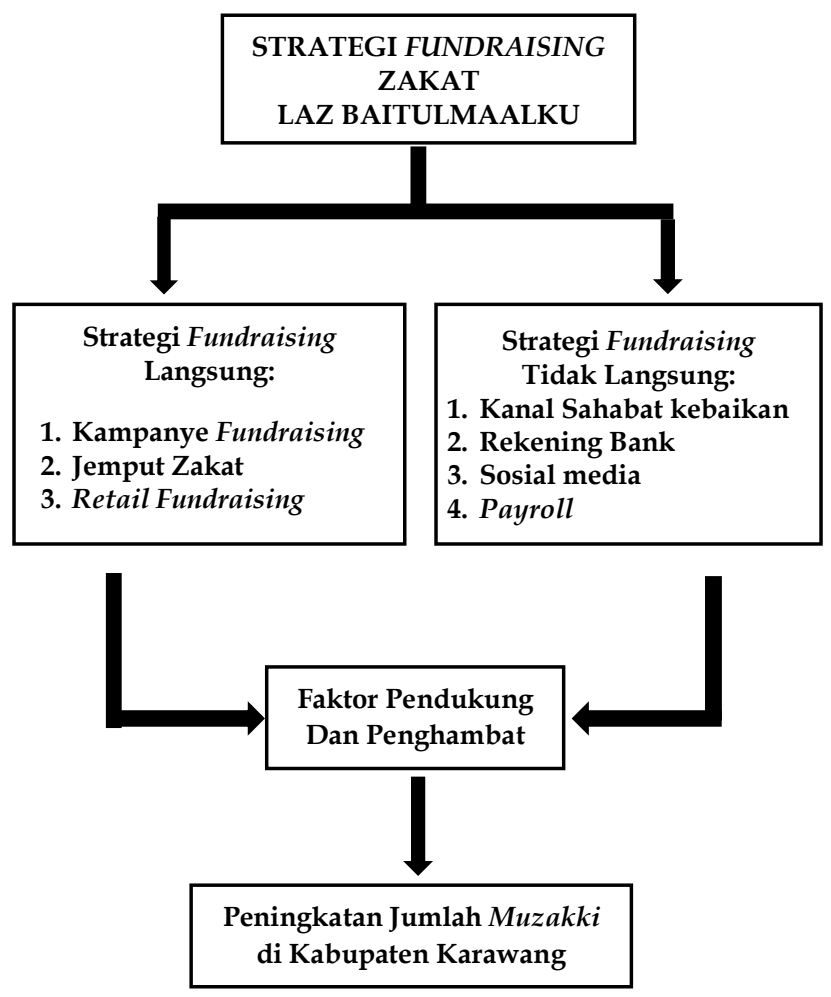

Gambar 2. Kerangka Pikir

\section{METODE PENELITIAN}

Penelitian ini menggunakan metode kualitatif, pengambilan data dengan 3 metode yaitu: observasi, wawancara, dan dokumentasi. Setelah data terkumpul, langkah selanjutnya, dengan tahapan analisis yaitu, reduksi data, penyajian data dan penarikan kesimpulan. Dan tempat penelitian sebagai populasi penelitian adalah Lembaga Amil 
Zakat (LAZ) BaitulMaalku di Jl. Jend. Ahmad Yani No. 427 Ruko Claster Primadona No. B1 Cikampek, Kabupaten Karawang 41373.

\section{HASIL DAN PEMBAHASAN}

\section{Analisis Strategi Fundraising Zakat LAZ BaitulMaalku Kab. Karawang}

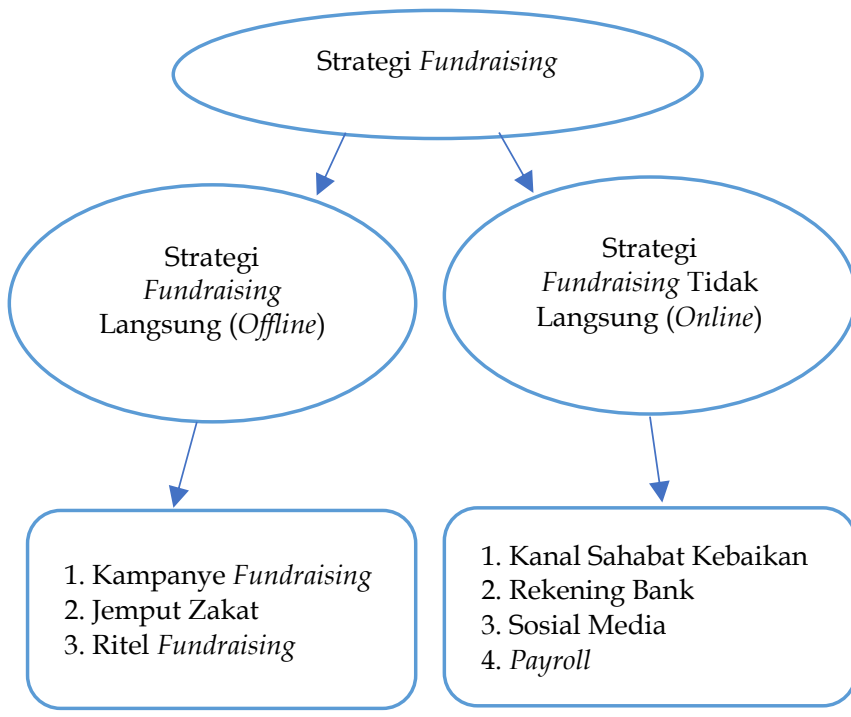

\section{Gambar 3. Skema Fundraising}

Strategi yang diterapkan di LAZ BaitulmaalKu terbagi menjadi 2 (dua) yaitu, strategi langsung atau offline dan strategi tidak langsung atau online. Strategi langsung atau offline ada 3 (tiga) strategi yang dilakukan yaitu, kampanye fundraising, jemput zakat, dan ritel fundraising. Sedangkan strategi tidak langsung atau online terbagi 4 (empat) strategi yaitu, kanal sahabat sahabat kebaikan, rekening bak, sosial media, payroll.

Berikut kutipan wawancara dengan informan struktural LAZ BaitulMaalKu, Maesya'bani (Wakil Direktur dan Bendahara) dan Deni Santoso (Staf Fundraising):

"Ada strategi secara Offline artinya menghimpun secara langsung zakat dari kaum muslimin disekitar wilayah karawang serta ada juga kegiatan rutin edukasi zakat yang sering di selenggarakan oleh baitulmaalku di masjid-masjid dan perusahaan. strategi secara online artinya menghimpun zakat secara digital melalui media-media sosial yang sering digunakan oleh sebagian orang, seperti WA (WhatsApp), Instagram, facebook, applikasi baitulmaalku membayar menggunakan dana, ovo, gopay, link aja, BCA mobile, juga rekening khusus zakat melalui Bank Mandiri syariah." (Santoso, 2020).

"Strategi offline, langsung ke calon muzakkinya, kita biasanya edukasi melalui majelis taklim, melalui masjid, melalui tools-tools offline, kayak spanduk dan lain-lain, kita juga ada fasilitas jemput zakat bisa juga melalui via transfer. Yang kedua ada digital fundraising, digital fundraising kita punya kanal namanya sahabat kebaikan.org disitu mas bisa liat ada campaign-campaign program juga programprogram zakat dan program-program infaq yang nantinya para muzakki itu bisa milih, langsung program yang mana, atau misal yaudah mba bebas program yang mana saja biasanya langsung transfer si, terus yang ketiga ada di melalui korporat, nah korporat itu di SDMnya udah ngumpulin zakat dari para karyawan otomatis payroll dipotong tiap gajian, kemudian baru kerjasama sama kita gitu di transferkan ke rekening baitulmaalku, nah itu yang memang yang lumayan besar yah karena langsung dari instansi atau perusahaan." (Maesya'bani, 2020).

Metode secara langsung (offline) adalah metode yang menggunakan teknik-teknik atau cara-cara yang melibatkan partisipasi muzakki secara langsung. Yaitu bentuk-bentuk fundraising di mana proses interaksi dan daya akomodasi terhadap respon muzakki bisa seketika atau langsung dilakukan. Dengan metode ini apabila dalam diri muzakki muncul keinginan untuk melakukan donasi setelah mendapatkan promosi dari fundraiser lembaga, maka segera dapat melakukan dengan mudah dan semua kelengkapan informasi yang diperlukan untuk melakukan donasi sudah tersedia. Sebagai contoh dari metode ini adalah: Direct Mail, Direct Advertising, Telefundraising dan presentasi langsung. (Nopiardo, 2017: 63).

Adapun strategi langsung atau offline yang dilakukan LAZ BaitulMaalKu sebagai berikut:

1) Kampanye Fundraising

2) Jemput Zakat

3) Ritel Fundraising 
Metode secara tidak langsung (online) adalah suatu metode yang menggunakan teknik-teknik atau cara-cara yang tidak melibatkan partisipasi muzakki secara langsung. Yaitu bentuk-bentuk fundraising di mana tidak dilakukan dengan memberikan daya akomodasi langsung terhadap respon muzakki seketika. Metode ini misalnya dilakukan dengan metode promosi yang mengarah kepada pembentukan citra lembaga yang kuat, tanpa diarahkan untuk transaksi donasi pada saat itu. Sebagai contoh dari metode ini adalah: advertorial, image compaign dan penyelenggaraan Event, melalui perantara, menjalin relasi, melalui referensi, mediasi para tokoh, dan sebagainya. (Nopiardo, 2017: 63).

Penerimaan dana zakat di LAZ BaitulMaalKu dengan strategi tidak langsung (online), merupakan strategi yang paling efektif dalam menghimpun dana zakat dibandingkan dengan strategi yang langsung (offline). Adapun strategi tidak langsung atau online yang dilakukan LAZ BaitulMaalKu sebagai berikut:

1) Kanal Sahabat Kebaikan

2) Rekening Bank

3) Sosial Media

4) Payroll

Faktor Pendukung dan Faktor Penghambat Strategi Fundraising Zakat LAZ BaitulMaalKu

Adapun faktor-faktor pendukung yang mempengaruhi muzakki dalam menyalurkan zakatnya ke LAZ BaitulMaalKu yaitu;

1) Legalitas LAZ

2) Program-program yang jelas

3) Pelaporan yang transparan

4) Pemberdayaan mustahik

Dalam menghimpun zakat terdapat faktorfaktor yang menghambat, seperti;

1) Pemahaman masyarakat yang kurang

2) Penyaluran zakat secara tradisional

3) Adanya LAZ-LAZ yang beroperasi

4) Donatur yang belum mencapai nishab.

\section{Pembahasan}

Berdasarkan Analisa, peneliti berpendapat bahwa pelaksanaan strategi fundraising zakat dalam meningkatkan jumlah muzakki yang digunakan LAZ BaitulMaalKu sudah sesuai dengan teori, yaitu menggunakan metode direct fundraising atau BaitulMaalKu menyebutnya Metode Offline atau secara Langsung, dan metode indirect fundraising atau BaitulMaalKu biasanya menyebutnya metode online. Dimana hasil dari dua metode tersebut yang lebih efektif yaitu metode online dibandingkan dengan yang offline atau langsung, hal ini dapat dibuktikan dengan table berikut:

\begin{tabular}{|c|c|c|c|c|}
\hline Tahun & $\begin{array}{c}\text { Jumlah } \\
\text { Dana Zakat } \\
\text { (Tahun) }\end{array}$ & $\begin{array}{c}\text { Jumlah } \\
\text { Rata-rata } \\
\text { Dana } \\
\text { Zakat } \\
\text { (Bulan) }\end{array}$ & $\begin{array}{c}\text { Jumlah } \\
\text { Muzakki } \\
\text { (Tahun) }\end{array}$ & $\begin{array}{c}\text { Jumlah } \\
\text { Rata- } \\
\text { rata } \\
\text { Muzakki } \\
\text { (Bulan) }\end{array}$ \\
\hline $\begin{array}{c}\text { Januari- } \\
\text { Desember } \\
(2018)\end{array}$ & 22.500 .000 & 1.875 .000 & 171 & 14 \\
\hline $\begin{array}{c}\text { Januari- } \\
\text { Desember } \\
\text { (2019) }\end{array}$ & 2.133 .415 .000 & 177.784 .583 & 1000 & 83 \\
\hline $\begin{array}{c}\text { Januari- } \\
\text { Agustus } \\
\text { (2020) }\end{array}$ & 1.923 .180 .000 & 240.397 .500 & 1000 & 125 \\
\hline
\end{tabular}

Diawal mulai beroperasi tahun 2018, LAZ BaitulMaalKu menggunakan strategi fundraising zakat dengan strategi langsung (offline) dan strategi tidak langsung (online) dalam penerimaan dana zakat, seperti dengan LAZ pada umumnya dalam memulai, tentu butuh waktu dalam memperoleh dana dengan jumlah yang besar. Untuk di tahun pertama beroperasi BaitulMaalKu berhasil menghimpun dana zakat perorangan sebesar Rp.22.500.000, dan jumlah muzakki 171 orang, dengan rata-rata muzakki perbulan hanya 14 orang. Namun untuk penerimaan dana ZIS 2018 sebesar Rp.619.387.850.

Di tahun, 2019 BaitulMaalKu mulai menunjukan hasil yang positif dengan menggunakan 2 strategi fundraising zakat, strategi langsung (offline) maupun strategi tidak langsung (online), dan bekerjasama dengan korporasi yang ada di Karawang, dalam penerapan strategi tidak langsung (online) melalui pemotongan otomatis gaji pegawai instansi terkait yang memenuhi wajib zakat, melalui rekening BaitulMaalKu, dengan rincian penerimaan dana zakat kemitraan Rp.2.131.247.500, dengan jumlah muzakki lebih dari 
1000, dan penerimaan dana zakat perorangan Rp.2.167.500, dengan jumlah muzakki 65, jadi total keseluruhan dana zakat Rp.2.133.415.000. Untuk strategi langsung (offline) mengalami penurunan dibandingkan di 2018. dimana jika dirata-rata jumlah muzakki perbulan ada sekitar 5 orang, penurunan dalam strategi langsung dalam menghimpun dana dan muzakki, namun di sisi lain strategi tidak langsung (online) mengalami peningkatan yang sangat baik, jika dibandingkan tahun sebelumnya.

Untuk di tahun 2020, yang terhitung sejak januari sampai dengan agustus tidak kalah bagus, dengan menggunakan strategi yang sama, namun lebih banyak inovasi-inovasi yang ditawarkan dalam memudahkan muzakki dalam menunaikan zakatnya di era modern ini, dan program-program yang membuat muzakki tertarik. Total jumlah penerimaan dana zakat yang masuk sebesar Rp.1.923.180.000, rata-rata jumlah dana yang masuk sebesar Rp.240.395.500.000 dalam sebulan, dengan rincian dana penerimaan zakat kemitraan korporasi sebesar 1.874.180.000, dan penerimaan dana zakat perorangan atau strategi langsung (offline) sebesar 48.960.000, dengan jumlah muzakki strategi langsung (offline) sebanyak 288 dengan rata-rata jumlah muzakki sebanyak 36 orang. Ini jumlah yang baik dengan peningkatan yang baik dibandingkan tahun lalu.

Dengan demikian kedua strategi tersebut bersifat saling melengkapi dan harus dijalankan secara bersamaan. Sedangkan dalam aspek fundraising zakat di BaitulMaalKu yaitu penghimpunan dana zakat mengikuti jumlah minimal 3 miliyar sesuai dengan kebijakan mandatori dari Kementerian Agama skala Kabupaten/Kota yaitu 3 Miliyar. Namun tidak kunjung tercapai. Dalam hal ini BaitulMaalKu lebih memprioritaskan besar dana yang ingin dicapai dari pada jumlah muzakki, sebab semakin banyak jumlah dana yang diperoleh, maka meningkat juga jumlah muzakki-nya. Menurut pandangan penulis, program-program BaitulMaalku sudah tepat, sebab dalam praktiknya hampir semua program-program yang ada dapat terlaksana dengan baik, dan LAZ
BaitulMaalKu memiliki legalitas payung hukum yang jelas.

\section{KESIMPULAN}

Berdasarkan hasil penelitian yang sudah penulis lakukan, dan berdasarkan uraian-uraian di BAB sebelumnya, maka dapat disimpulkan bahwa strategi fundraising zakat dalam meningkatkan jumlah muzakki di LAZ BaitulMaalKu, yaitu menggunakan 2 (dua) strategi, yang pertama Strategi Langsung (Offline) seperti kampanye fundraising, pelayanan jemput zakat, dan ritel fundraising yaitu sosialisasi dan edukasi zakat ke majelis taklim dan perusahaan-perusahaan. Kedua, Strategi tidak langsung (online), diantaranya melalui kanal sahabat kebaikan, media-media sosial, melalui rekening zakat, dan payroll atau kerjasama kemitraan dengan korporasi yang ada di karawang.

Dengan strategi yang sudah diterapkan oleh LAZ Baitulmaalku, terbukti telah meningkatkan jumlah muzakki di BaitulMaalKu pada tahun 2018 berjumlah 171 muzakki dan dana yang terkumpul Rp.22.500.000, mengalami peningkatan di tahun 2019, menjadi 1000 lebih muzakki dan dana penerimaan zakat sebesar Rp.2.133.415.000, begitu juga di tahun 2020 sampai bulan agustus, jumlah muzakki ada lebih dari 1000 dan penerimaan dana zakat sebesar Rp.1.923.180.000, strategi yang dinilai paling efektif adalah strategi tidak langsung (online), yaitu payroll melalui transfer rekening kerjasama kemitraan dengan korporasi yang ada di Karawang.

Untuk faktor-faktor pendorong strategi fundraising zakat dalam meningkatkan jumlah muzakki di LAZ BaitulMaalKu, yaitu adanya legalitas lembaga, program-program Santunan Jompo setiap bulan, program pemberdayaan mustahik, Beasiswa dhuafa/ siswa-siswi berprestasi, Dan program-program lainnya yang bisa membuat muzakki tertarik menunaikannya di BaitulMaalku. Sedangkan faktor penghambat strategi fundraising zakat di LAZ BaitulMaalKu, yaitu Pengetahuan tentang zakat sebagian masyarakat masih kurang, sebagian masyarakat lebih percaya kepada tokohtokoh agama dan ada juga masyarakat yang menyalurkan secara langsung, Lembaga Amil Zakat berjamuran di tengah-tengah masyarakat walaupun 
legalitas lembaga tersebut tidak ada, dan Lembaga filantropi Islam LAZNAS melakukan fundraising di Kabupaten Karawang.

\section{DAFTAR PUSTAKA}

Abidah, Atik, Kodifikasia, Volume 10, Nomor 1, Analisis Strategi Fundraising Terhadap Peningkatan Pengeloaan ZIS pada Lembaga Amil Zakat Kabupaten Ponorogo, Ponorogo: STAIN Ponorogo, 2016.

Afifi, Agus Thayib, dan Ika, Shabira, Kekuatan Zakat: Hidup Berkah Rezeki Melimpah, Yogyakarta, Albana Pustaka, 2010.

Burhani, R, Lahan Industri Karawang Mencapai 19.000 Hektare, Dipetik Juli 20, 2020, dari Antarnews.com:http://www.antarnews.com/ berita/361710/lahan-industri-karawang-capai19000-hektare.

Chaniago, Siti Aminah, Jurnal Hukum Islam, Volume 12, Nomor 1, Perumusan Manajemen Strategi Pemberdayaan Zakat, Pekalongan: Jurusan Syariah dan Ekonomi Islam STAIN Pekalongan, 2014.

Cooper, Donald R, dan Schindler, Pamela S, Metode Riset Bisnis. Jakarta: PT Media Global Edukasi, 2006.

Ghofur, Abdul, Tiga Kunci Fundraising, Sukses Membangun Lembaga Nirlaba, Jakarta: Gramedia Pustaka Utama, 2018.

Kasri, Rahmatina A, dan Putri, Niken Iwani S, Journal of Islamic Economics, Fundraising Strategis to Optimize Zakah Potential in Indonesia, An Exploratory Qualitative Study, Depok: Universitas Indonesia, 2018.

Kementerian Agama RI, Standarisasi Amil Zakat di Indonesia, Jakarta: Direktorat Jenderal Bimbingan Masyarakat Islam Direktorat Pemberdayaan Zakat, 2013.

Khasanah, Umrotul, Manajemen Zakat Modern: Instrumen Perberdaya Umat, Malang: UIN Maliki Press, 2010.

Komariah, Aan dan Satori, Djam'an, Metodologi Penelitian Kualitatif, Bandung: Alfabeta, 2014.
Mannan, M. Abdul, Teori dan Praktek Ekonomi Islam, Yogyakarta: Dana Bhakti Prima Yasa, 1997.

Moleong, J. Lexy, Metodologi Penelitian Kualitatif, Bandung: PT Remaja Rosdakarya, 2006.

Moleong, J. Lexy, Metode Penelitian Kualitatif, Bandung: PT. Remaja Rosdakarya, 2014.

Nasih, Ulwan Abdullah, Hukum Zakat Dalam Pandangan Empat Mazhab (diterjemahkan oleh Didin Hafidhuddin), Jakarta: Lentera Antar Nusa, 1985.

Nopiardo, Widi, Jurnal Imara, Strategi Fundraising Dana Zakat Pada Baznas Kabupaten Tanah Datar, Volume 1, nomor 1, Tanah Datar: Fakultas Ekonomi dan Bisnis Islam IAIN Batusangkar, 2017.

Purnomo, Setiawan Hari, Manajemen Strategi, Sebuah Konsep Pengantar, Jakarta: Fakultas Ekonomi Universitas Indonesia, 1996.

Purwanto, April, Manajemen Fundraising Bagi Organisasi Pengelola Zakat, Yogyakarta: Sukses, 2009.

Qardawi, Dr. Yusuf, Hukum Zakat, Cetakan keduabelas, Jakarta: Pustaka Litera Antar Nusa, 2011.

Rais, Isnawati, Muzakki dan Kriteria dalam Tinjauan Fiqih Al-Iqtishad, Semarang: Pustaka Rizki Putra Ghazali, 2009.

Rangkuti, Freddy, Analisis Swot Teknik Membedah Kasus Bisnis, Reorientasi Konsep Perencanaan Strategis Untuk Menghadapi Abad 21, Jakarta: Gramedia Pustaka Utama, 2006.

Rosadi, Aden, Zakat dan Wakaf, Konsepsi Regulasi dan Implementasi, Bandung: Rekatama Media, 2019.

Sekaran, Uma, Metode Penelitian Untuk Bisnis, Jakarta: Salemba Empat, 2017.

Wikaningtyas, Suci Utami, dan Sulastiningsih, Jurnal Riset Manajemen, Vol. 2, No.1, Strategi Penghimpuna Dana Zakat pada Organisasi Pengelolaan Zakat di Kabupaten Bantul, Yogyakarta: STIE Widya Wiwaha, 2015.

Yusuf, A. M, Kuantitatif, Kualitatif, \& Penelitian Gabungan. Jakarta: Kencana, 2014. 
